\title{
Population biology of eyeflukes in fish from a large fluvial ecosystem: the importance of gulls and habitat characteristics
}

\author{
D.J. Marcogliese, S. Compagna, E. Bergeron, and J.D. McLaughlin
}

\begin{abstract}
Spottail shiners (Notropis hudsonius) were monitored for eyeflukes monthly at four sites in the St. Lawrence River, Quebec, from spring through autumn in 1997 and 1998. In general, mean abundance of Diplostomum spp. in the lens of spottail shiners was highest at sites near large ring-billed gull (Larus delawarensis) colonies and was higher in 1998 than in 1997. Population studies demonstrated a major period of recruitment in the late summer - early autumn. Mean abundance increased between November and May, when sampling was logistically not possible, reflecting latefall or early-spring recruitment. Golden shiners (Notemigonus crysoleucas) and small yellow perch (Perca flavescens) were monitored at a single site (Île aux Ours) in 1997 and 1998. Mean abundance of Diplostomum spp. in the lens of golden shiners at Île aux Ours was higher in 1998 than in 1997. Recruitment occurred in the early summer and between November and May, suggesting late-fall or early-spring transmission. Mean abundance decreased between August and October in both years. Yellow perch at Île aux Ours were infected with four different parasite species in their eyes. Mean abundance of Diplostomum spp. in the vitreous humour or retina increased during the summer and fall and then decreased between the fall and following spring. Diplostomum spp. in the lens increased in abundance in the early summer, and then decreased during the fall. Both Tylodelphys scheuringi and Neascus spp. in the vitreous humour were more abundant in 0+ than in 1+ perch. Mean abundance of T. scheuringi increased over the summer in 1997 and then dropped to zero in the same cohort over winter, suggesting that the parasite lives for only 1 year. Neascus spp. only were found in 1998. Distributional data, together with seasonal information, suggest that habitat characteristics contribute significantly to the abundance of Diplostomum spp. along the St. Lawrence River. Proximity to gull colonies enhances abundance, but higher rates of predation at wetland sites depress abundance and restrict the accumulation of parasites.
\end{abstract}

Résumé : L'infection par la douve de l'oeil chez le Queue à tache noire (Notropis hudsonius) a fait l'objet d'un suivi mensuel du printemps à l'automne 1997 et 1998, à quatre sites du fleuve Saint-Laurent, Québec. En général, l'abondance moyenne de Diplostomum spp. dans les cristallins des Queues à tache noire était plus élevée aux sites localisés à proximité des colonies de Goélands à bec cerclé (Larus delawarensis) et était également plus élevée en 1998 qu'en 1997. Les études de populations ont mis en évidence l'existence d'une période de pointe pour le recrutement de Diplostomum spp., à la fin de l'été et au début de l'automne. Des Chattes de l'Est (Notemigonus crysoleucas) et des Perchaudes (Perca flavescens) de petites tailles, échantillonnés à un site (île aux Ours), ont également été examinés en 1997 et 1998. Comme dans le cas de $N$. hudsonius, l'abondance moyenne de Diplostomum spp. dans les cristallins des Chattes de l'Est à l'île aux Ours était plus élevée en 1998 qu'en 1997. Une première phase de recrutement du parasite s'est produite au début de l'été et une deuxième entre novembre et mai, ce qui semble indiquer une transmission automnale tardive ou printanière hâtive. On a observé une diminution de l'abondance moyenne entre août et octobre au cours des 2 années d'échantillonnage. Les yeux des perchaudes de l'île aux Ours étaient infectés par quatre espèces de parasites. L'abondance moyenne de Diplostomum spp. dans l'humeur vitreuse ou la rétine des perchaudes a subi une augmentation au cours de l'été et de l'automne pour ensuite décroître entre la fin de l'automne et le printemps suivant. Les Diplostomum spp. dans les cristallins ont augmenté en abondance au début de l'été pour ensuite diminuer au cours de l'automne. Tylodelphys scheuringi et Neascus spp. dans l'humeur vitreuse étaient plus abondants chez les perchaudes 0+ par comparaison avec des poissons âgés de 1 an. L'abondance moyenne de T. scheuringi au sein d'une cohorte de perchaudes s'est accrue au cours de l'été 1997 pour ensuite tomber à zéro durant l'hiver, ce qui indique que la longévité de ce parasite n'excède pas 1 année. Des Neascus spp. furent observés uniquement en 1998. Les données relatives à la distribution et aux fluctuations saisonnières de Diplostomum spp. suggèrent que les caractéristiques d'habitat exercent une influence significative sur l'abondance de ce parasite chez les poissons du fleuve Saint-Laurent. Si la proximité des colonies de goélands accroît l'abondance de la douve de l'oeil, les taux de prédation plus élevés des jeunes poissons dans les milieux humides pourraient contribuer à réduire l'abondance et limiter l'accumulation de ce parasite.

Received January 3, 2001. Accepted May 10, 2001. Published on the NRC Research Press Web site at http://cjz.nrc.ca on June 25, 2001.

D.J. Marcogliese, ${ }^{\mathbf{1}}$ S. Compagna, E. Bergeron. St. Lawrence Centre, Environment Canada, 105 McGill Street, 7th Floor, Montreal, QC H2Y 2E7, Canada.

J.D. McLaughlin. Department of Biology, Concordia University, 1455 de Maisonneuve Boulevard West, Montreal, QC H3G 1M8, Canada.

${ }^{1}$ Author to whom correspondence should be addressed (e-mail: david.marcogliese@ec.gc.ca). 


\section{Introduction}

Eyeflukes (Diplostomum spp.) are extremely common parasites of freshwater fish globally, infecting over 100 species (Chappell et al. 1994; Chappell 1995). These trematodes are considered an important parasitic pathogen of wild and farmed fish, causing blindness, poor growth, emaciation, deformities, and mortality (Shariff et al. 1980; Chappell 1995). Though few data exist, the parasite is considered a problem in the St. Lawrence River in eastern Canada, where it causes cataracts in at least 12 species of fish (see Marcogliese and Compagna 1999). Amphibians in the system were also infected at moderately high levels (Marcogliese et al. 2000).

The population biology of the parasite is well known in other systems. Typically, recruitment occurs in the spring and fall and the parasite accumulates in fish over time. The seasonality of recruitment patterns is attributed to the combined effects of the life cycle of the lymnaeid snail intermediate hosts and water temperature (Wootten 1974; Kennedy and Burrough 1977; Burrough 1978; Brassard et al. 1982b; Stables and Chappell 1986a; McKeown and Irwin 1997). However, most of these studies were restricted to lakes, reservoirs, small rivers, and aquaculture facilities. There are few studies of geographic variation in and population dynamics of parasites in large fluvial systems such as the St. Lawrence River. Thus, the seasonal dynamics of Diplostomum spp. were examined over 2 years in minnows and young perch from different types of habitat, including the fluvial corridor and wetland areas, in relation to the distribution of the larid definitive host, the ring-billed gull (Larus delawarensis Ord). This study demonstrates that the population dynamics of the eyeflukes are influenced by the proximity of gull colonies, but are also influenced differentially by habitat characteristics and food-web structure.

\section{Materials and methods}

Four localities on the St. Lawrence River, Quebec, between Montreal and Lake St. Pierre were sampled monthly between May and October in 1997 and 1998 (Fig. 1). From west to east these include the Champlain Bridge $\left(45^{\circ} 28^{\prime} 00^{\prime \prime} \mathrm{N}, 73^{\circ} 29^{\prime} 48^{\prime \prime} \mathrm{W}\right)$, Île de la Couvée $\left(45^{\circ} 28^{\prime} 30^{\prime \prime} \mathrm{N}, 73^{\circ} 30^{\prime} 20^{\prime \prime} \mathrm{W}\right)$, Île Deslauriers $\left(45^{\circ} 42^{\prime} 42^{\prime \prime} \mathrm{N}\right.$, $\left.73^{\circ} 26^{\prime} 36^{\prime \prime} \mathrm{W}\right)$, and Île aux Ours $\left(46^{\circ} 07^{\prime} 54^{\prime \prime} \mathrm{N}, 73^{\circ} 03^{\prime} 00^{\prime \prime} \mathrm{W}\right)$. Île de la Couvée also was sampled in April and November 1998. A fifth locality, Île du Nord $\left(46^{\circ} 07^{\prime} 42^{\prime \prime} \mathrm{N}, 73^{\circ} 02^{\prime} 48^{\prime \prime} \mathrm{W}\right)$, was sampled monthly August through October 1998. The localities at the Champlain Bridge and Île de la Couvée are located near the shipping lanes of the South Shore Canal adjacent to La Prairie Basin. Both localities have hard rock and (or) shale bottoms with little submergent vegetation. The Île Deslauriers locality has a hard clay bottom, with some submergent vegetation far from shore. Île aux Ours and Île du Nord are located in the Lake St. Pierre archipelago. The former locality is heavily vegetated with emergent and submergent vegetation on soft muddy substrate and the latter has a hard sandy bottom. Île Deslauriers and Île de la Couvée are both home to major ring-billed gull breeding colonies numbering 48767 and 20870 pairs, respectively, in 1997 (P. Brousseau, Canadian Wildlife Service, personal communication). Surface temperature was measured using a hand-held thermometer.

Fish were collected by a seine $(22.6 \times 1.15 \mathrm{~m}, 3-\mathrm{mm}$ mesh $)$ deployed from an open boat. Fish were killed by an overdose of MS $222\left(0.2 \mathrm{~g} \cdot \mathrm{L}^{-1}\right)$ and examined fresh or frozen for subsequent analysis. All fish were measured for fork length and weighed. The eyes were removed, dissected, and examined for parasites. Parasites were identified, counted, and their site (lens, vitreous humour, or retina) within the eye was recorded. Three species of fish were examined. Spottail shiners (Notropis hudsonius (Clinton)) were collected at the Champlain Bridge, Île de la Couvée, Île Deslauriers, and sporadically at Île aux Ours and Île du Nord. Given that spottail shiners were difficult to collect at Île aux Ours, golden shiners (Notemigonus crysoleucas (Mitchill)) and yellow perch (Perca flavescens (Mitchill)) were collected from that site as well. Fish were classified into year classes based on distributions in lengthfrequency histograms. This method was effective for fish in our samples and has been used previously for spottail shiners (Peer 1966).

Metacercarial stages of eyeflukes are difficult to identify to species, and resolution of the group's taxonomy must be completed before individuals can be assigned to species (Chappell 1995; Gibson 1996). In North America, metacercariae found in the lens of fish are typically assigned to Diplostomum spathaceum (Rudolphi), those in the vitreous humour to Diplostomum huronense (La Rue), those in the vitreous humour and retina of salmonids to Diplostomum baeri bucculentum Dubois and Rausch, and those on the retina of perch to Diplostomum adamsi Lester and Huizinga, but these identifications based on metacercariae must be regarded with caution (Gibson 1996). Furthermore, when fish are frozen prior to examination, metacercariae detach from the retina and appear to be vitreous humour forms, which possibly leads to misidentification based on presumed site specificity. We have tentatively identified three species based on adults obtained by feeding lenses and whole eyes of particular species of fish to laboratory-reared ring-billed gulls. The adults raised from metacercariae from the vitreous humour and retina of perch are identified provisionally as Diplostomum baeri Dubois. The lens forms, obtained by feeding lenses thoroughly washed in screens to gulls, are of two morphological types. One type with a large anterior testis is provisionally identified as $D$. huronense; the other corresponds to Diplostomum indistinctum (Guberlet). Washed lenses from 86 spottail shiners fed to four 8-week-old gulls yielded 95 flukes, 81 of which corresponded to $D$. indistinctum. The rest $(14$, or about $15 \%)$ corresponded to $D$. huronense. The results are comparable to infections using material from other sources, where $84-92 \%$ of the parasites were $D$. indistinctum and the rest $D$. huronense (Marcogliese et al. 2001). Although there are background levels of $D$. huronense, $D$. indistinctum is the dominant species. At present there is no way to distinguish the metacercariae in fish samples and there are no data at present to suggest that their ecology and transmission differ. Accordingly, we have designated all of the metacercariae in the lens as Diplostomum spp. for purposes of analysis, fully cognizant of the fact that two species are present, albeit disproportionately, in the host population.

Tylodelphys scheuringi (Hughes) was identified according to Gibson (1996), but it should be acknowledged that a second species, Tylodelphys podicipina Kozicka and Niewadomska, is known from grebes in western Canada (Stock and Holmes 1987). Parasites of the subfamily Crassiphialinae (Posthodiplostomum minimum (MacCallum), Ornithodiplostomum ptychocheilus (Faust)) are referred to by their larval genus, Neascus spp. Both can be found in various fish tissues (Gibson 1996). Two species of Posthodiplostomum have been positively identified from great blue herons (Ardea herodias L.) collected in the sampling vicinity (J.D. McLaughlin, unpublished data).

Prevalence (the proportion of fish infected, expressed as a percentage), mean abundance (the mean number of parasites of a given taxon per fish examined), and mean intensity (the mean number of parasites of a given taxon per infected fish) are defined in Bush et al. (1997). Because data could not be normalized and did not adhere to the assumptions of parametric statistics, all data were analyzed using the nonparametric Kruskal-Wallis or Mann-Whitney $U$ tests. Samples with $<10$ fish were not included in the above 
Fig. 1. Map of the St. Lawrence River, Quebec, Canada, showing sampling sites (fish icons), ring-bill gull (Larus delawarensis) colonies (bird icons), and other localities mentioned in the text.

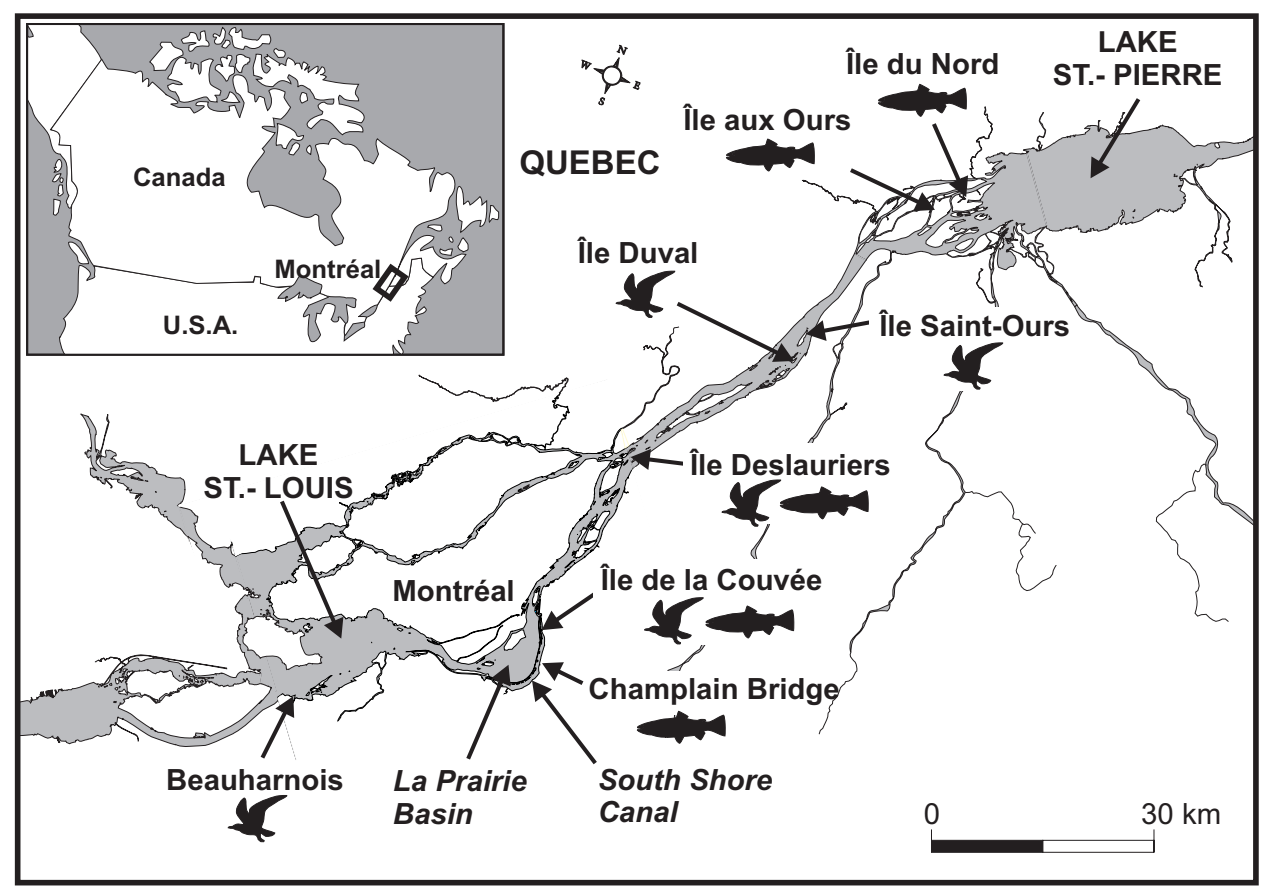

Table 1. Summary statistics of infections of Diplostomum spp. in the lens of $0+$ and $1+$ spottail shiners (Notropis hudsonius) from various sites in the St. Lawrence River in 1997-1998.

\begin{tabular}{lllllll}
\hline Site & $\begin{array}{l}\text { Sampling } \\
\text { year }\end{array}$ & Age & $N$ & $\begin{array}{l}\text { Prevalence } \\
(\%)\end{array}$ & $\begin{array}{l}\text { Abundance } \\
(\text { mean } \pm \text { SD) }\end{array}$ & $\begin{array}{l}\text { Intensity } \\
(\text { mean } \pm \text { SD) }\end{array}$ \\
\hline Île Deslauriers & 1997 & $0+$ & 173 & 61.9 & $1.3 \pm 1.7$ & $2.1 \pm 1.8$ \\
& 1997 & $1+$ & 28 & 96.4 & $9.5 \pm 7.6$ & $9.8 \pm 7.5$ \\
& 1998 & $0+$ & 58 & 81.0 & $2.7 \pm 2.2$ & $3.3 \pm 1.9$ \\
Champlain Bridge & 1998 & $1+$ & 101 & 96.0 & $6.5 \pm 10.4$ & $6.8 \pm 10.5$ \\
& 1997 & $0+$ & 359 & 20.0 & $0.3 \pm 0.7$ & $1.5 \pm 0.7$ \\
& 1997 & $1+$ & 68 & 64.7 & $2.0 \pm 3.8$ & $3.1 \pm 4.3$ \\
Île de la Couvée & 1998 & $0+$ & 91 & 35.2 & $0.6 \pm 1.1$ & $1.8 \pm 1.1$ \\
& 1998 & $1+$ & 170 & 56.5 & $2.5 \pm 2.6$ & $3.2 \pm 2.5$ \\
& 1997 & $0+$ & 457 & 21.9 & $0.3 \pm 0.7$ & $1.4 \pm 0.8$ \\
Île aux Ours & 1997 & $1+$ & 186 & 71.0 & $1.9 \pm 2.8$ & $2.6 \pm 3.0$ \\
& 1998 & $0+$ & 133 & 53.4 & $1.5 \pm 2.9$ & $2.9 \pm 3.5$ \\
& 1998 & $1+$ & 133 & 82.7 & $3.9 \pm 10.8$ & $4.8 \pm 11.9$ \\
& 1997 & $0+$ & 22 & 63.6 & $0.8 \pm 0.9$ & $1.3 \pm 0.8$ \\
Île du Nord & 1997 & $1+$ & 40 & 87.5 & $5.1 \pm 5.6$ & $5.9 \pm 5.6$ \\
\hline
\end{tabular}

analyses. Correlation analyses were performed on parasite numbers of the different species in the eyes of yellow perch to determine the occurrence of interspecific interactions.

\section{Results}

\section{Spottail shiners}

Infection with Diplostomum spp. in spottail shiners was principally confined to the lens of the eye: only 8 Diplostomum spp. metacercariae were found in the vitreous humour of 3 fish over the 2 years. Prevalence, mean abundance, and mean intensity increased with age at each site (Table 1). Statistical analyses are restricted to those Diplostomum spp. found in the lens, as they consist predominantly of a single species (D. indistinctum) with background levels of a second species (D. huronense). Neascus spp., and T. scheuringi were rarely found in spottail shiners. Only 3 fish were found infected with $T$. scheuringi in the lens or vitreous humour, whereas a total of 12 fish were infected with 14 Neascus spp. in the vitreous humour.

Fish from Île Deslauriers were generally more heavily infected than fish in each age-class from other sites (Table 1). Spatial variations in mean abundance were found within ageclasses of spottail shiners. Among young-of-the-year (YOY) 
fish, those from Île Deslauriers had a significantly higher abundance of Diplostomum spp. than those from Ile de la Couvée and Champlain Bridge in 1997 and fish from all sites in 1998 (Kruskal-Wallis test, $P<0.0001$ ). Among $1+$ fish, mean abundance in those from Île Deslauriers was significantly higher than in those from from Île de la Couvée, the Champlain Bridge, and Île aux Ours in 1997, and mean abundance in those from îles Deslauriers and de la Couvée was higher than in those from other localities in 1998 (KruskalWallis test, $P<0.0001)$. Fish of age $1+$ from Île aux Ours had a higher mean abundance of Diplostomum spp. than those from Île de la Couvée and Champlain Bridge in 1997.

Localities compared on a monthly basis (Fig. 2) further demonstrated that Diplostomum spp. were more abundant at Île Deslauriers. In August and September 1998, YOY spottail shiners from Île Deslauriers and Île de la Couvée had higher mean abundances of Diplostomum spp. than those from other localities. For the month of May 1998, among 1+ fish Diplostomum spp. were more abundant at Île Deslauriers than at other localities and more abundant at Île de la Couvée than at Île aux Ours (Kruskal-Wallis test, $P<0.0001$ ). For the month of June, mean abundances of Diplostomum spp. in $1+$ fish were significantly greater at Île Deslauriers and Île aux Ours than at the Champlain Bridge and Île de la Couvée in 1997, and more abundant at Île Deslauriers than at Île de la Couvée in 1998 (Kruskal-Wallis test, $P<0.0001$ ).

Interannual variations were detected in infection levels of Diplostomum spp. in spottail shiners, and indicated that mean abundances were higher in 1998 than in 1997. Among 0+ fish from all localities pooled together, mean abundance was significantly higher in August and September in 1998 than in 1997 (Mann-Whitney $U$ test, $P<0.0001$ ), but not in July or October $(P>0.05)$. On a site-by-site basis, mean abundance was higher in 1998 than in 1997 at the Champlain Bridge (Mann-Whitney $U$ test, $P=0.0015)$, Île de la Couvée $(P<0.0001)$, and Île Deslauriers $(P<0.0001)$, but the reverse was true for Île aux Ours $(P=0.0005)$. Among $1+$ fish from all localities pooled together, mean abundance was significantly higher in 1998 than in 1997 in June (MannWhitney $U$ test, $P=0.0014)$, but higher in 1997 than in 1998 in July $(P=0.0028)$, with no difference in September $(P>0.05)$. On a site-by-site basis, Diplostomum spp. were significantly more abundant in 1+ fish at Île de la Couvée in 1998 than in 1997 (Mann-Whitney $U$ test, $P=0.0083$ ), but more abundant in 1997 than in 1998 at Île Deslauriers $(P=$ 0.0016) and Île aux Ours $(P<0.0001)$.

Abundance of Diplostomum spp. varied monthly at various sites (Fig. 2), being higher in the late summer and fall than in earlier months. Mean abundance in YOY spottail shiners from Île Deslauriers was significantly higher in October than in September 1997 and in September than in August 1998 (Kruskal-Wallis test, $P<0.0001$ ) (Fig. 2A). At the Champlain Bridge, mean abundance in $0+$ spottail shiners was significantly higher in September than in July and August 1997, and in October than in August or September 1998 (Kruskal-Wallis test, $P<0.0001$ ) (Fig. 2C). At Île de la Couvée, mean abundance of Diplostomum spp. in YOY fish was significantly greater in September and October 1997 than in July and August 1997, and greater in August through October than in July 1998 (Kruskal-Wallis test, $P<0.0001$ ) (Fig. 2B). Among 1+ fish, mean abundance at the Cham- plain Bridge was significantly greater in spottail shiners collected in July than in those collected in May 1998 (KruskalWallis test, $P<0.0001$ ) (Fig. 2C).

To follow infection levels in the same cohort across years, mean abundances of Diplostomum spp. were compared among months at each site for YOY fish in 1997 and 1+ fish in 1998. Mean abundance was usually higher in the spring and early summer than during the preceding fall within the same cohort. At Île Deslauriers, parasite abundance in May and June of 1998 was significantly greater than in September and October 1997 (Kruskal-Wallis test, $P<0.0001$ ) (Fig. 2A). At the Champlain Bridge, mean abundance in April, May, and July 1998 was significantly higher than in July, August, and September 1997 (Kruskal-Wallis test, $P<$ 0.0001) (Fig. 2C). At Île de la Couvée, mean abundance of Diplostomum in 1+ fish in May and June 1998 was significantly greater than in YOY fish collected in July through October 1997 (Kruskal-Wallis test, $P<0.0001$ ) (Fig. 2B).

\section{Golden shiners}

Diplostomum spp. were relatively rare in the vitreous humour or on the retina of golden shiners. A total of 13 worms were found in the vitreous humour of 6 fish over 2 years. Statistical analyses are restricted to Diplostomum spp. found in the lens. As with spottail shiners, prevalence, mean abundance, and mean intensity increased with age (Table 2). No T. scheuringi were observed in the eyes of golden shiners. With the exception of the July 1997 sample, Neascus spp. were relatively uncommon. A total of 30 Neascus spp. were found in 21 infected fish, 13 of which were collected in July 1997.

Annual variations were detected in abundance of Diplostomum spp. in golden shiners collected from Île aux Ours, with overall abundance significantly higher in 1998 than in 1997 for $0+$ fish (Mann-Whitney $U$ test, $P<0.0001$ ) (Table 2). On a monthly basis, mean abundance in $0+$ fish in September $(P=0.0002)$ and October $1998(P=0.0433)$ was significantly higher than in the corresponding months in 1997. For 1+ fish, metacercariae in July 1998 significantly outnumbered those in July 1997 (Mann-Whitney $U$ test, $P<$ 0.0001), but not for August through October $(\mathrm{P}>0.05)$ (Fig. 3).

Monthly variations in abundance of Diplostomum spp. in golden shiners were noted within years. Mean abundance of Diplostomum spp. in 1+ fish in July through September was higher than in May and June 1998 (Kruskal-Wallis test, $P<$ 0.0001) (Fig. 3). Mean abundance decreased significantly between August and October 1998 ( $P<0.0001)$. Mean abundance also decreased between August and October 1997 in 1+ fish, but the difference was not significant (Fig. 3).

Infection levels were followed in the same cohort over time by comparing monthly mean abundances of Diplostomum sp. in YOY golden shiners in 1997 with 1+ fish in 1998. Mean abundance was significantly higher in 1+ fish in May and in July through October 1998 than in YOY fish in September and October 1997 (Kruskal-Wallis test, $P<0.0001$ ) (Fig. 3).

Infection levels were compared between spottail and golden shiners collected at the same time from Île aux Ours. Among YOY fish, mean abundance of Diplostomum spp. was greater in spottail shiners $(0.8 \pm 0.9(\mathrm{SD}))$ than in golden shiners $(0.5 \pm 0.8)$ collected in October 1997 (Kruskal-Wallis 
Fig. 2. Monthly mean abundances of Diplostomum spp. in the lens of spottail shiners (Notropis hudsonius) from Île Deslauriers (A), Île de la Couvée (B), the Champlain

Bridge (C), and Île aux Ours and Île du Nord in Lake St. Pierre (D) from June 1997 to October 1998. Vertical lines indicate SE. Fish are divided into cohorts according to year of birth. Cohort 1996 were 1+ in 1997. Cohort 1997 were 0+ in 1997 and 1+ in 1998. Cohort 1998 were 0+ in 1998. Numbers above each data point are sample sizes.

\section{A. Île Deslauriers}

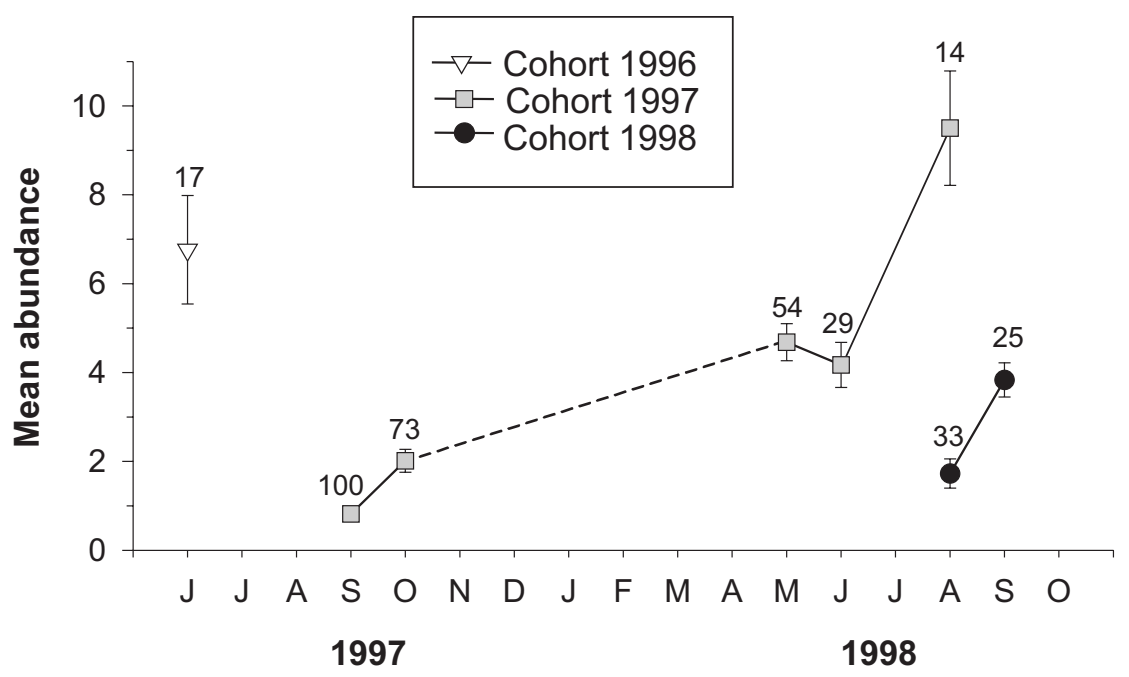

\section{Champlain Bridge}

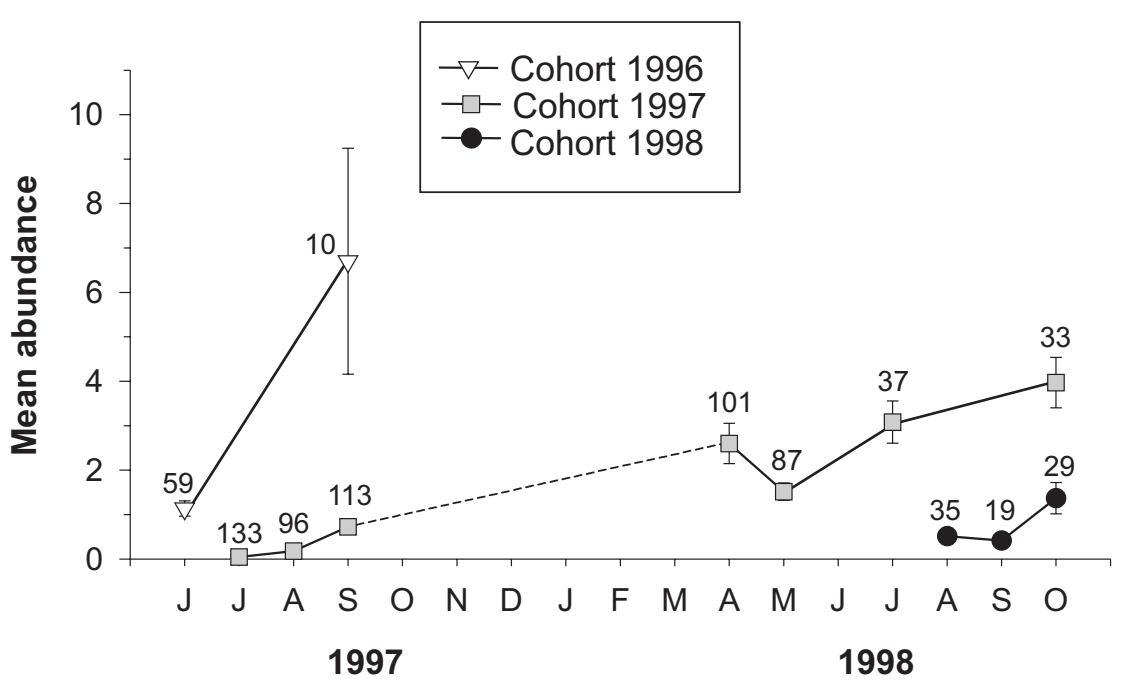

B. Île de la Couvée

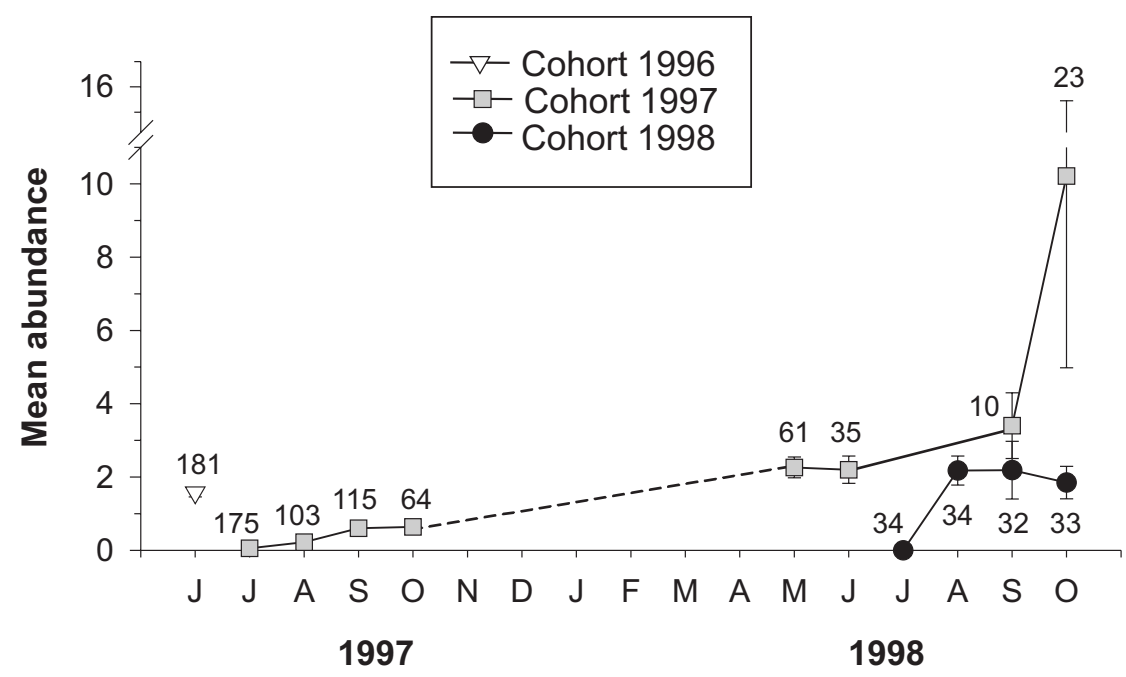

D. Lake St. Pierre

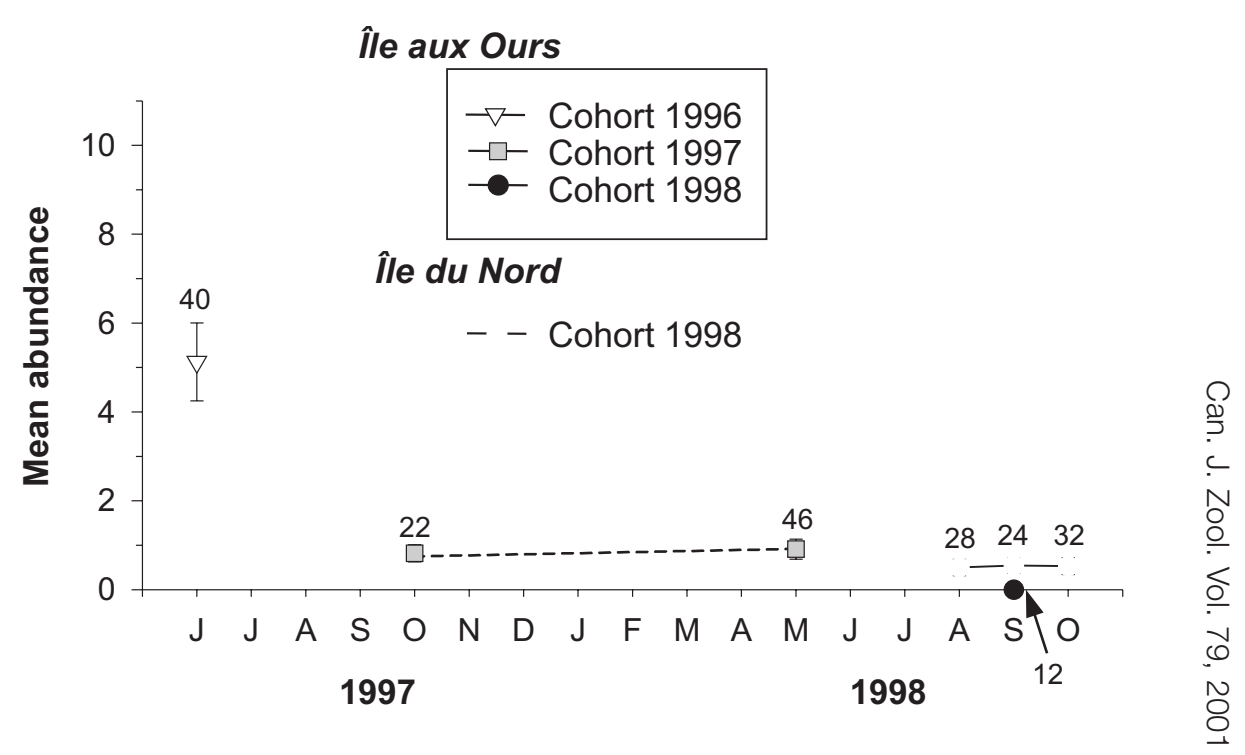


Fig. 3. Monthly mean abundances of Diplostomum spp. in the lens of golden shiners (Notemigonus crysoleucas) from Île aux Ours from June 1997 to October 1998. Vertical lines indicate SE. Fish are divided into cohorts according to year of birth. Cohort 1996 were $1+$ in 1997. Cohort 1997 were 0+ in 1997 and $1+$ in 1998. Cohort 1998 were 0+ in 1998. Numbers above each data point are sample sizes.

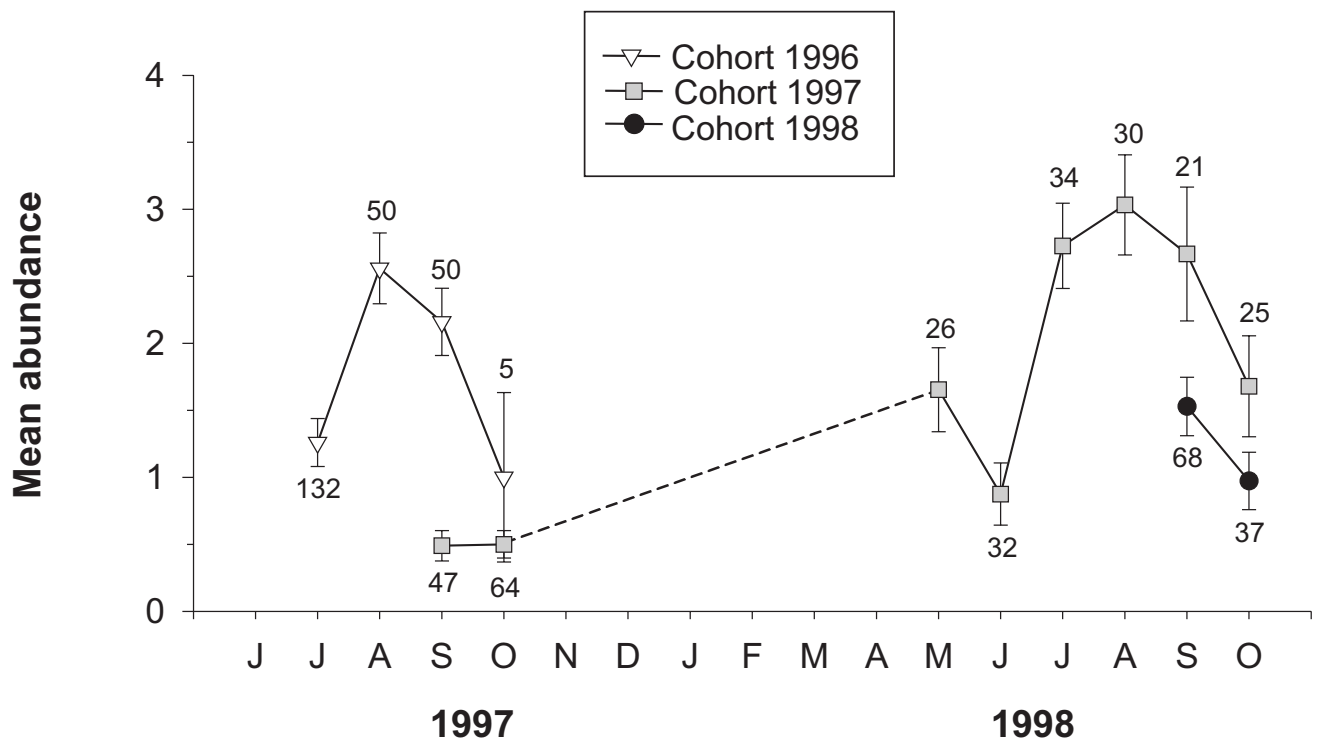

Table 2. Summary statistics of infections of Diplostomum spp. in the lens of $0+$ and $1+$ golden shiners (Notemigonus crysoleucas) from Île aux Ours in Lake St. Pierre, the St. Lawrence River, in 1997-1998.

\begin{tabular}{llllll}
\hline $\begin{array}{l}\text { Sampling } \\
\text { year }\end{array}$ & Age & $N$ & $\begin{array}{l}\text { Prevalence } \\
(\%)\end{array}$ & $\begin{array}{l}\text { Abundance } \\
(\text { mean } \pm \text { SD) }\end{array}$ & $\begin{array}{l}\text { Intensity } \\
(\text { mean } \pm \text { SD) }\end{array}$ \\
\hline 1997 & $0+$ & 113 & 33.6 & $0.5 \pm 0.8$ & $1.5 \pm 0.7$ \\
1997 & $1+$ & 245 & 73.1 & $1.8 \pm 2.2$ & $2.5 \pm 2.2$ \\
1998 & $0+$ & 104 & 61.0 & $1.3 \pm 1.7$ & $2.2 \pm 1.6$ \\
1998 & $1+$ & 167 & 76.0 & $2.1 \pm 2.0$ & $2.8 \pm 1.8$ \\
\hline
\end{tabular}

test, $P=0.0316)$, while the reverse was true for September 1998 (golden shiners: $1.5 \pm 1.8$; spottail shiners: 0$)(P<$ $0.0001)$. For $1+$ fish collected in May 1998, Diplostomum spp. metacercariae in golden shiners $(2.5 \pm 1.6)$ significantly outnumbered those in spottail shiners $(0.9 \pm 1.5)$ (KruskalWallis test, $P=0.0072)$. Summarized data for $0+$ and $1+$ fish demonstrated a higher abundance in spottail shiners in 1997 (Kruskal-Wallis test, $P=0.0253$ ) and the reverse in 1998 (Kruskal-Wallis test, $P=0.0002$ ).

\section{Yellow perch}

Perch from Île aux Ours were infected with different species of parasites in the lens, the vitreous humour, and the retina (Table 3). Diplostomum spp. were found in the lens, vitreous humour, and retina. Lens forms were treated separately from the vitreous-humour and retinal forms, as they probably constitute different species. It was difficult to distinguish vitreous-humour from retinal forms in frozen fish, as the parasites detach from the retina upon freezing. Among fresh fish, parasites were observed on the retina only. Thus, vitreous-humour and retinal forms are considered together and referred to as vitreous-humour forms. Tylodelphys scheuringi and Neascus spp. were found in the vitreous humour. No Neascus spp. were found in 1997.

The various parasites were compared between age groups of yellow perch. Both T. scheuringi and Neascus spp. were significantly more abundant in $0+$ perch than in $1+$ perch (Mann-Whitney $U$ test, $P=0.0275$ and $<0.0001$, respectively; Table 3).

Abundances of parasites in perch were compared between years. In July and August, abundance of T. scheuringi was significantly greater in 1998 than in 1997 (Mann-Whitney $U$ test, $P=0.0015$ and 0.0158 , respectively) (Fig. 4C). Metacercariae of Diplostomum spp. in the lens in August and October of 1998 significantly outnumbered those in the corresponding months in 1997 (Mann-Whitney $U$ test, $P=$ 0.0223 and 0.0006, respectively), whereas for September, they were significantly more abundant in 1997 than in 1998 $(P=0.0357)$ (Fig. 4B).

Abundances of the different parasites in perch were compared monthly to determine whether there were seasonal trends (Fig. 4). Mean abundance of Diplostomum spp. in the vitreous humour of YOY perch increased significantly between July-August and September-October in 1997 and 1998 (Kruskal-Wallis test, $P<0.0001$ ) (Fig. 4A). There were no significant differences in mean abundance of $T$. scheuringi among months except for an increase between May and June 1998 in $1+$ perch (Kruskal-Wallis test, $P=0.0106$ ) (Fig. 4C). No significant trends were observed for Diplostomum spp. in the lens or for Neascus spp. (Figs. 4B, 4D).

Parasite abundances were followed over time in the same cohort of fish, using monthly values for 0+ fish in 1997 and 
Table 3. Summary statistics of infections of Diplostomum spp. in the lens and in the vitreous humour or retina, Tylodelphys scheuringi in the vitreous humour, and Neascus spp. in the vitreous humour of $0+$ and $1+$ yellow perch (Perca flavescens) from Ile aux Ours in Lake St. Pierre, the St. Lawrence River, in 1997-1998.

\begin{tabular}{|c|c|c|c|c|c|c|}
\hline & $\begin{array}{l}\text { Sampling } \\
\text { year }\end{array}$ & Age & $N$ & $\begin{array}{l}\text { Prevalence } \\
(\%)\end{array}$ & $\begin{array}{l}\text { Abundance } \\
(\text { mean } \pm \mathrm{SD})\end{array}$ & $\begin{array}{l}\text { Intensity } \\
(\text { mean } \pm \mathrm{SD})\end{array}$ \\
\hline Diplostomum spp. (lens) & 1997 & $0+$ & 209 & 11.5 & $0.2 \pm 0.7$ & $1.5 \pm 1.4$ \\
\hline Diplostomum spp. (vitreous humour and retina) & 1997 & $0+$ & 209 & 28.7 & $0.4 \pm 1.0$ & $1.7 \pm 1.4$ \\
\hline T. scheuringi & 1997 & $0+$ & 209 & 4.3 & $0.1 \pm 0.4$ & $1.4 \pm 1.0$ \\
\hline Neascus spp. & 1997 & $0+$ & 209 & 0 & 0 & 0 \\
\hline Diplostomum spp. (lens) & 1998 & $0+$ & 134 & 21.6 & $0.3 \pm 0.7$ & $1.5 \pm 0.7$ \\
\hline Neascus spp. & 1998 & $0+$ & 134 & 41.0 & $1.4 \pm 3.0$ & $3.2 \pm 3.9$ \\
\hline Diplostomum spp. (lens) & 1998 & $1+$ & 62 & 27.4 & $0.3 \pm 0.7$ & $1.2 \pm 0.8$ \\
\hline Diplostomum spp. (vitreous humour and retina) & 1998 & $1+$ & 62 & 32.3 & $0.6 \pm 1.3$ & $1.9 \pm 1.7$ \\
\hline T. scheuringi & 1998 & $1+$ & 62 & 9.7 & $0.1 \pm 0.3$ & $1.0 \pm 0$ \\
\hline Neascus spp. & 1998 & $1+$ & 62 & 0 & 0 & 0 \\
\hline
\end{tabular}

$1+$ fish in 1998. When comparisons were made between the last month of sampling (October) of 0+ fish in 1997 and the first month of sampling of 1+ fish in 1998, mean abundance of the lens form of Diplostomum spp. was significantly greater in 1998 than in 1997 (Kruskal-Wallis test, $P=0.0011$ ) (Fig. 4B). Mean abundance of Diplostomum spp. in the vitreous humour was significantly higher in $0+$ fish in October 1997 than in 1+ fish in May 1998 (Kruskal-Wallis test, $P=$ 0.0326) (Fig. 4A). While significant differences were not detected, it is important to note that mean abundance of T. scheuringi dropped to zero between October 1997 and May 1998 (Fig. 4C). Corresponding declines in prevalence were observed.

Abundances of the different parasites were compared with each other to determine if there were differences among species. When data were pooled, in 1997 Diplostomum spp. in the vitreous humour significantly outnumbered those in the lens and T. scheuringi in the vitreous humour of YOY perch (Kruskal-Wallis test, $P<0.0001$ ). This relationship did not hold for July and August $(P>0.05)$, but was significant in September and October $(P<0.0001)$. In 1998 , overall mean abundance of Neascus spp. was significantly greater than abundances of Diplostomum spp. in the lens and vitreous humour, and that of $T$. scheuringi in the vitreous humour (Kruskal-Wallis test, $P<0.0001$ ). On a monthly basis, Neascus spp. were significantly more numerous in $0+$ perch than the vitreous-humour form of Diplostomum spp. in $\mathrm{Au}-$ gust 1998 (Kruskal-Wallis test, $P=0.03$ ), and more numerous than all 3 parasites in September $1998(P<0.0001)$, but numbers were not significantly different in July or October $(P>$ 0.05). Among 1+ perch in 1998 the overall mean abundance of Diplostomum spp. in the vitreous humour was significantly greater than abundances of $T$. scheuringi and Neascus spp. (Kruskal-Wallis test, $P<0.0001$ ). On a monthby-month basis, both forms of Diplostomum spp. had mean abundances significantly higher than those of $T$. scheuringi and Neascus spp. in May 1998 (Kruskal-Wallis test, $P<$ 0.0001). Mean abundance of Diplostomum spp. in the vitreous humour was significantly greater than abundances of T. scheuringi and Neascus spp. in June 1998 (Kruskal-Wallis test, $P=0.0014)$. There were no negative correlations among the parasites in the eyes of yellow perch. The abundance of
Diplostomum spp. in the right lens was positively correlated with that of $T$. scheuringi in the right vitreous humour $(r=$ $0.12, P=0.0154)$.

\section{Discussion}

The spottail shiner is an appropriate species for monitoring parasite populations. Spottail shiners consist of local populations (Suns and Rees 1978) and are common in the St. Lawrence River. In the Great Lakes, they are used as indicator organisms for contaminants in fish (Suns and Rees 1978). Furthermore, there are distinct advantages to examining young of the year, in that their parasites must have been acquired that year and not accumulated from infections during previous years. Therefore, seasonal periods of recruitment in long-lived parasites such as Diplostomum spp. can be determined without interference from the confounding effects of older infections.

Abundance patterns of Diplostomum spp. in spottail shiners demonstrate annual, seasonal, and geographic variations along the St. Lawrence River. Generally, Diplostomum spp. were more abundant at localities close to gull colonies than at those farther away; more abundant near the largest gull colony; most abundant in the late summer and autumn; and sometimes more abundant in 1998 than in 1997, though the annual trends are equivocal.

Infection levels tend to be highest at Île Deslauriers, which has by far the largest ring-billed gull colony in the St. Lawrence River basin, numbering 48767 pairs in 1997. This relationship holds for both $0+$ and $1+$ fish. At times, abundance is also higher in $0+$ and $1+$ fish at Île de la Couvée than at some other sites. Île de la Couvée has the second largest nesting colony of gulls along the river, totaling 20870 pairs in 1997. Thus, the importance of gulls in influencing infection levels of Diplostomum spp. is evident. Fish from the locality at the Champlain Bridge usually had infections similar in abundance to those from Île de la Couvée, located about $0.5 \mathrm{~km}$ downstream. The difference observed between Île de la Couvée and the Champlain Bridge in October 1998 reinforces the assertion that spottail shiners occur in locally distributed populations. Interestingly, spottail shiners from Île aux Ours in Lake St. Pierre were occasionally 
Fig 4. Monthly mean abundances of parasites in the eyes of yellow perch (Perca flavescens) from Île aux Ours from June 1997 to October 1998. (A) Diplostomum spp. in the vitreous humour. (B) Diplostomum spp. in the lens. (C) Tylodelphys scheuringi in the vitreous humour. (D) Neascus spp. in the vitreous humour. Vertical lines indicate SE.

Fish are divided into cohorts according to year of birth. Cohort 1996 were 1+ in 1997. Cohort 1997 were 0+ in 1997 and 1+ in 1998. Cohort 1998 were 0+ in 1998. Numbers

above each data point are sample sizes.

\section{A. Diplostomum spp. (vitreous humour)}

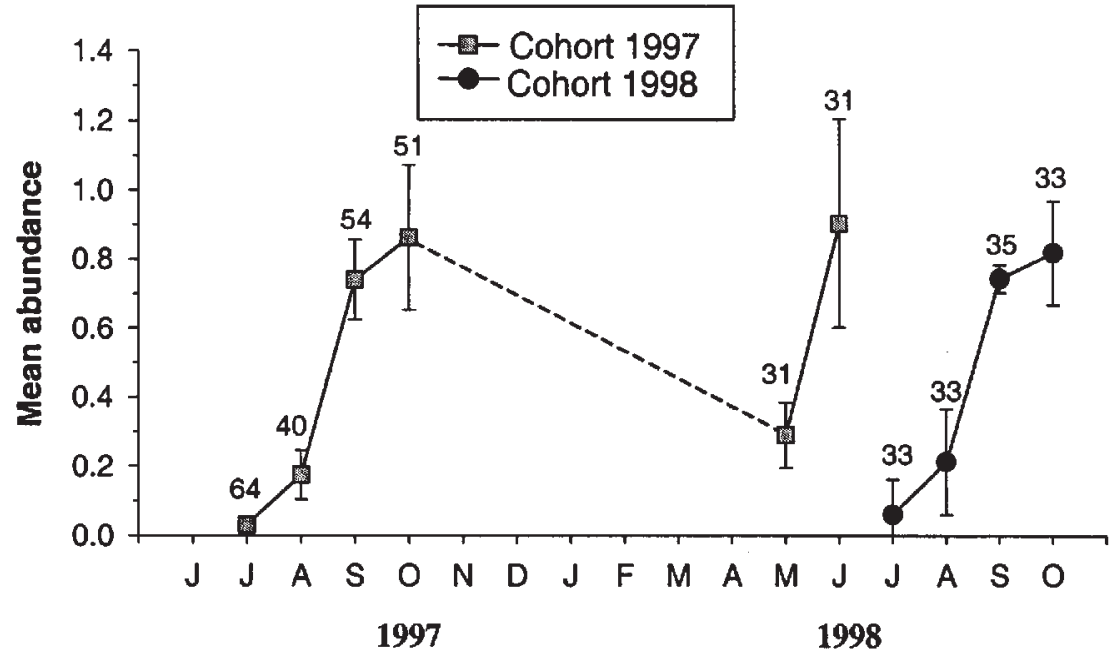

\section{Tylodelphys scheuringi}

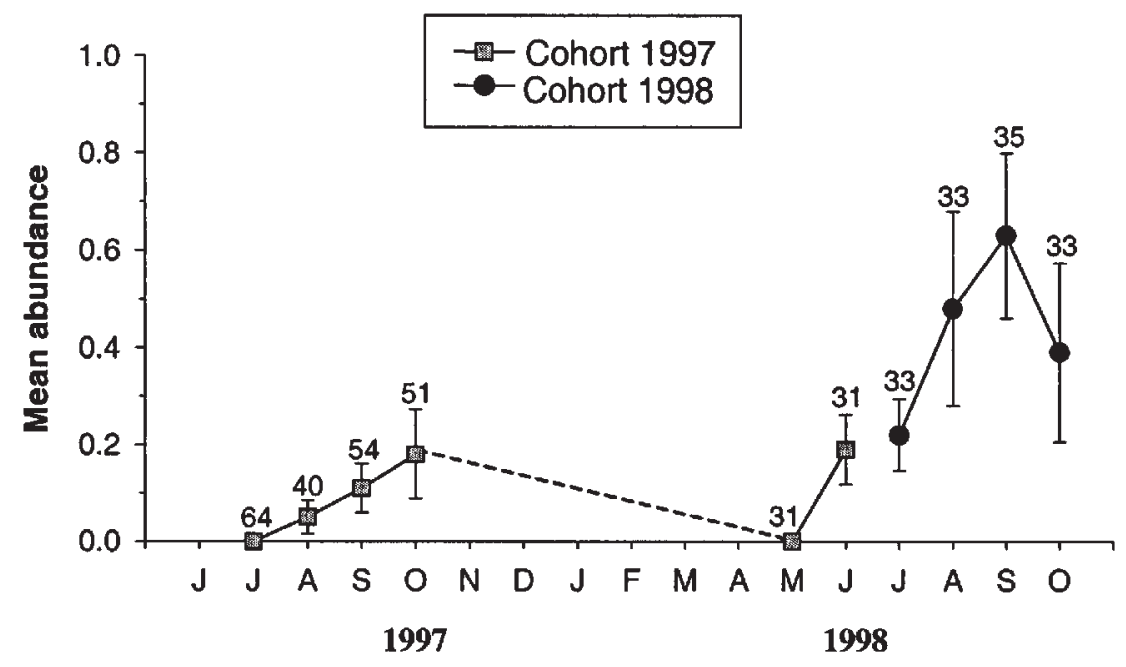

\section{B. Diplostomum spp. (lens)}

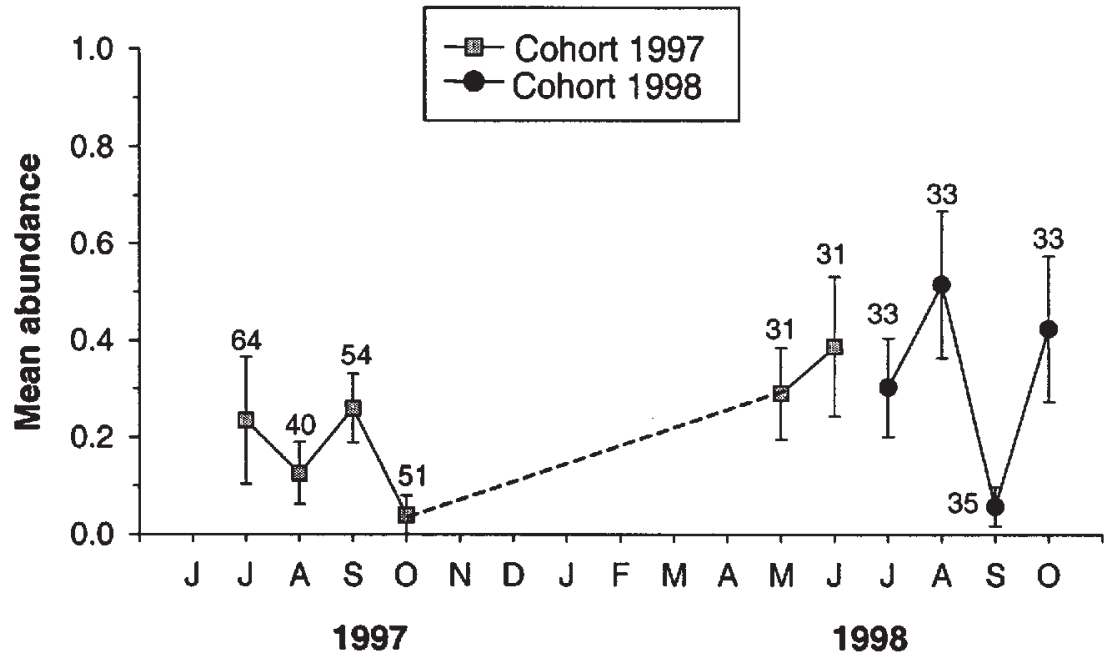

\section{Neascus spp.}

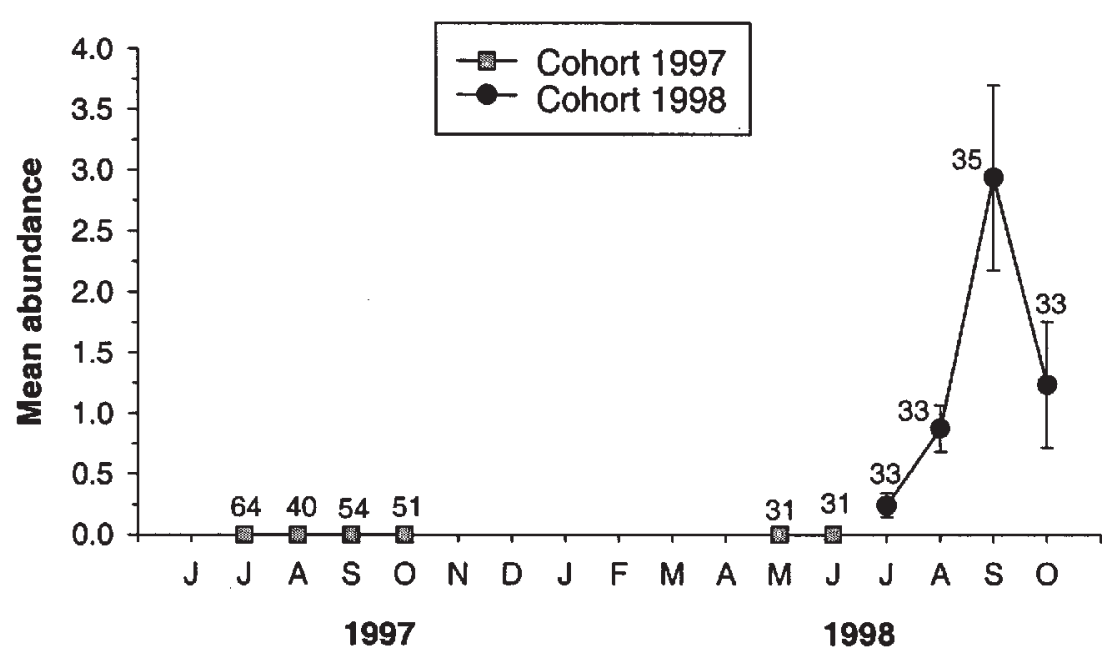


more heavily infected than those from Île de la Couvée and the Champlain Bridge, despite the fact that the closest major gull colonies, numbering $<16000$ pairs, are located $27 \mathrm{~km}$ upstream at Îles Saint-Ours and Duval. Île aux Ours is located in a productive wetland area with prolific emergent vegetation, the most suitable of all localities for pulmonate snails such as lymnaeids, the first intermediate host for Diplostomum spp. However, mean abundance of Diplostomum spp. in gulls from Île Saint-Ours $(9 \pm 10)$ was less, but not significantly so, than that in gulls from Île de la Couvée ( $24 \pm$ 38 ) in 1994-1995, while prevalences were similar (80 and 90\%, respectively) (Levy 1997).

The annual differences in abundance of Diplostomum spp. in YOY and 1+ spottail shiners are inconsistent. Overall patterns showed an increase between 1997 and 1998 in the same year classes. In 0+ fish, late-summer abundances were higher in 1998 than in 1997, and this could be related to the higher temperatures that occurred in 1998, thus promoting parasite development and cercarial release in the snail intermediate hosts. Water temperature varied from 15 to $17^{\circ} \mathrm{C}$ among localities in September 1997 and from 18 to $20^{\circ} \mathrm{C}$ in 1998. The higher levels at Île de la Couvée and the Champlain Bridge in 1998 may be attributed to an increase in the size of the gull colony at Île de la Couvée. The colony expanded onto a small island to the west, occupying more area in 1998 (D.J. Marcogliese, personal observation). In contrast, among 1+ fish, infection levels were higher in June 1998 than in June 1997, but the reverse was true for July. In addition, infection levels were higher at Îles aux Ours and Deslauriers in 1997 than in 1998. These data are complicated by the fact that $1+$ fish have undergone more than 1 year of parasite recruitment. YOY fish provide a more accurate indication of annual recruitment, and these data suggest higher infections in 1998 than in 1997.

No historic data on eyefluke infections in freshwater fish from the St. Lawrence River are available to determine annual trends. Nesting data indicate that the population of gulls on Île de la Couvée was actually larger in 1990 and 1994, numbering 28-30 000 pairs (Environment Canada 2000). This suggests that Diplostomum spp. infections have been consistently high for at least a few years. Media attention has focused on the problem of blindness in St. Lawrence River fish since at least 1995, and blind fish were reported in surveys of fishes between 1989 and 1991 (Gagnon et al. 1991, 1992). Surveys of spottail shiners in the Great Lakes between 1961 and 1975 demonstrate prevalences of D. spathaceum between 3 and $20 \%$ in lakes Superior, Huron, and Erie, but 76\% in Lake Ontario (Dechtiar and Christie 1988; Dechtiar and Lawrie 1988; Dechtiar and Nepszy 1988; Dechtiar et al. 1988), though Bangham (1955) found 60\% of spottail shiners in Lake Huron to be infected in 1951.

Data provided herein demonstrate a distinct period of recruitment of Diplostomum spp. in spottail shiners at all sites in the late summer. Moreover, by following an individual cohort between years, it can be shown that fish recruited infections between October and April-May. It cannot be ascertained whether the recruitment occurred in the late autumn or early spring. Often there are two periods of recruitment of Diplostomum spp. metacercariae in other systems, spring and autumn (Kennedy and Burrough 1977; Burrough 1978; Brassard et al. 1982b; McKeown and Irwin
1997). Such a pattern is often attributed to the annual life cycle of snail intermediate hosts. Infections overwinter in snails, and cercariae are released when temperatures rise in the spring. These snails reproduce, then die. Thus, parasite recruitment by fish slows or stops. The new generation of snails becomes infected, releasing cercariae in the late summer and autumn. Cercarial production shuts down as temperatures drop, and these snails overwinter (Kennedy and Burrough 1977; Burrough 1978; Brassard et al. 1982b). If the snails lived for more than 1 year, cercarial production would be continuous during the summer. Gulls acquire infections early in the year (Levy 1997), and most likely worms produce eggs on a continuous basis.

Cercarial release and transmission to fish are assumed to occur when the water temperature exceeds $10^{\circ} \mathrm{C}$ (Wootten 1974; Brassard et al. 1982b; Stables and Chappell 1986a, $1986 b$; McKeown and Irwin 1997). In the St. Lawrence River, the water normally reaches this temperature in April and drops below it in October. It is possible that recruitment occurred either late in the autumn after the sampling program had been terminated or early in the spring before it commenced (or both). However, the surface temperature was $10^{\circ} \mathrm{C}$ in November 1997 and $9^{\circ} \mathrm{C}$ in April 1998 at Île de la Couvée. Thus, theoretically, transmission to fish should not have occurred between these dates. In another study, shedding of D. spathaceum by infected Lymnaea stagnalis (L.) peaked at $20^{\circ} \mathrm{C}$, but cercariae were observed at temperatures as low as $4-6^{\circ} \mathrm{C}$, and they were infective, albeit to a low degree, at $7^{\circ} \mathrm{C}$ (Lyholt and Buckmann 1996). Lyholt and Buckmann (1996) proposed the existence of different ecotypes within $D$. spathaceum possessing different thermal optima. Unfortunately, sampling is problematic late in the autumn because when water temperatures drop, fish become difficult to collect, presumably because they are in deeper water. In the spring before May, the flow rate in the St. Lawrence river is usually extremely high, making sampling dangerous. In addition, where sampling is possible, fish are difficult to collect, again presumably because they are in deeper water.

Patterns of infection appeared to vary among species of cyprinid. For fish collected at the same time, spottail shiners tended to be more heavily infected than golden shiners in 1997, but the reverse was true in 1998. Comparisons are difficult to interpret because spottail shiners were collected only sporadically early and late in the field season. Golden shiners tended to be more heavily infected in 1998 than in 1997, paralleling observations in spottail shiners at other sites. As with the spottail shiners, these results may be attributable to an increase in the number of gulls or the higher temperatures in the St. Lawrence River in 1998, especially during the late summer, or both.

As in the spottail shiners, mean abundance increased between October 1997 and May 1998 in the same cohort of fish. Thus, recruitment of parasites occurred in the late fall or early spring. Given that the surface temperature was $9^{\circ} \mathrm{C}$ at Île aux Ours in October, but had already reached $21^{\circ} \mathrm{C}$ by the following May, cercarial release and transmission were most likely well underway before collections were made in the spring of 1998. Records of Diplostomum spp. in other systems are scarce, but D. spathaceum was found in $13 \%$ of golden shiners from Lake Ontario (Dechtiar and Christie 
1988), and Diplostomulum sp. was recorded in those from Lake of the Woods, Ontario (Dechtiar 1972).

Curiously, mean abundance of Diplostomum spp. declined in golden shiners between August and October in each year, the drop being significant in 1998. Prevalence and mean intensity dropped at the same time. Given that the parasite accumulates and survives for a number of years in fish, this decline could be the result of mortality of heavily infected fish at this site. No such decline was observed in spottail shiners at the other localities. Small fish in other systems appear to suffer from mortality induced by high intensities of Diplostomum spp. (McKeown and Irwin 1997). Moreover, parasite-induced susceptibility to predation has been demonstrated experimentally in guppies (Poecilia reticulata Peters) infected with D. spathaceum and exposed to brook trout (Salvelinus fontinalis (Mitchill)) (Brassard et al. 1982a). Dace (Leuciscus leuciscus (L.)) heavily infected with D. spathaceum spent more time in surface waters, possibly increasing their vulnerability to visually oriented predators (Crowden and Broom 1980). Île aux Ours is unique among the sampling localities in that it is heavily vegetated with submergent and emergent vegetation. Predatory fishes such as northern pike (Esox lucius L.) and smallmouth bass (Micropterus dolomieui Lacépède) were more common there than at other localities (D.J. Marcogliese, personal observation). Thus, the seasonal dynamics of Diplostomum spp. in minnows in the St. Lawrence River may be affected by habitat quality in terms of their suitability as prey for piscivorous fish. Removal of three-spined sticklebacks (Gasterosteus aculeatus L.) heavily infected with Diplostomum gasterostei Williams was observed by Pennycuick (1971), who attributed the phenomenon to parasite-induced mortality or susceptibility to predation.

Although no such declines in abundance of Diplostomum spp. were noted in spottail shiners, this does not necessarily imply that there are no negative effects on these fish. Mean intensity was > 4.5 in $1+$ spottails from Île aux Ours and 4.8-25.5 in $2+$ fish at the various sites. Owen et al. (1993) found that intensities of Diplostomum spp. as low as 4 can affect the response of three-spined sticklebacks to prey items, and 7 metacercariae can decrease the reactive distance to prey. High intensities in dace also decrease the reactive distance to prey and reduce feeding efficiency (Crowden and Broom 1980). Yet effects on condition were not detected (Crowden and Broom 1980), as in spottail shiners in this study (data not shown).

Yellow perch from Île aux Ours were infected by four types of parasites in their eyes, including Diplostomum spp., T. scheuringi, and Neascus spp. in the vitreous humour or retina and Diplostomum sp. in the lens. In 1997, Diplostomum spp. in the vitreous humour was the most common parasite in 0+ perch, whereas Neascus spp. was the most common in 0+ perch in 1998, with the vitreous-humour form of Diplostomum spp. most abundant in $1+$ perch that year. Neascus spp. and T. scheuringi were more common in $0+$ than in $1+$ perch, and both parasites were more abundant in 1998 than in 1997, Neascus spp. not actually being found in 1997.

The increased abundance of $T$. scheuringi in 1998 compared with 1997 is similar to what was observed for Diplostomum spp. in spottail and golden shiners. As in the case of Diplostomum spp., the higher abundance of $T$. scheuringi in 1998 may have been the result of higher temperatures accelerating larval trematode development and transmission. However, there were no differences in abundance of the vitreous-humour form of Diplostomum spp. between years, and results for the lens forms were inconsistent. This parasite has been found in perch from various lakes in southern Ontario, including Lake Ontario (Tedla and Fernando 1969, 1970).

It is interesting that Neascus spp. and T. scheuringi were more common in younger fish, suggesting that $0+$ fish may be more susceptible to infection than older perch. Moreover, it seems likely that $T$. scheuringi possesses a short but perhaps variable life-span and does not accumulate in fish from year to year as does Diplostomum spp. This hypothesis is supported by the observation that no $T$. scheuringi were found during the first month of sampling in 1+ fish in 1998, implying that parasites did not survive over winter. Similar conclusions regarding life-span were obtained for Tylodelphys clavata (Nordmann) (1 year) and Tylodelphys podicipina (2 years) in perch (Perca fluviatilis L.), roach (Rutilus rutilus (L.)), and rudd (Scardinius eryphthalmus (L.) in Slapton Ley (Kennedy and Burrough 1977; Burrough 1978; Kennedy 1987). Kennedy and Burrough (1977) and Kennedy (1981) observed comparable winter declines in prevalence of T. clavata in perch, in one year dropping to zero. Wootten (1974) also found T. podicipina to be mainly in 0+ and 1+ perch, with highest abundances in 0+ fish. Kennedy (1987) stated that perch only become infected with $T$. podicipina during their first year, and that re-infection after the first year of life was impossible, suggesting an immune response. Burrough (1978) observed small (<130 mm) roach and rudd to be more heavily infected with $T$. clavata.

The appearance of Neascus spp. in the vitreous humour of spottail shiners, golden shiners, and yellow perch is intriguing. The only other report of this type of metacercaria in eyes is in brassy minnows (Hybognathus hankinsoni Hubbs), creek chub (Semotilus atromaculatus (Mitchill), and mosquitofish (Gambusia affinis (Baird and Girard)), (Hendrickson 1978; Hoffman 1999). Neascus spp. only appeared in perch in 1998, and yet became quite common. Conceivably, the avian piscivorous host introduced the parasite to the locality. The two species of Tylodelphys were introduced into Slapton Ley in 1973 and 1978, probably due to colonization by breeding pairs of great-crested grebes (Podiceps cristatus (L.)), which first appeared in 1973 (Kennedy and Burrough 1977; Kennedy 1987).

Monthly changes in the population dynamics of Diplostomum sp. in the vitreous humour of perch clearly indicate that transmission to YOY fish occurs in late summer, slowing down after September. This pattern of recruitment is slightly different from that seen in the lens of shiners, implying that this is a different species of Diplostomum. Examination of experimental infections of gulls with metacercariae from fish collected in the St. Lawrence River indicates that the vitreous-humour form from perch is D. baeri, while the lens form from other fishes consists of $D$. indistinctum and D. huronense. There is also a significant decline in abundance, which was coincident with declines in prevalence, mean intensity, and variance/mean ratio, within a cohort between October 1997 and May 1998, suggesting that heavily infected fish may be killed off during this interval. Tedla and 
Fernando (1969) suggested that yellow perch with the heaviest infections of $D$. huronense in their vitreous humour may die off. As was noted when discussing the decline in abundance within the same cohort of golden shiners, piscivory by predatory fish in this wetland habitat may selectively remove the more heavily infected perch, accounting for the decline between the fall of 1997 and the spring of 1998 . Holmes (1979) made the prediction that populations of parasites maturing in a host will decrease with increasing predation pressure on that host. From the results reported herein, a corollary to that prediction may be deduced: that the population of larval parasites in a host will decrease with increased predation pressure from non-host predators. While the predatory fish that abound in the locality may serve as intermediate hosts for Diplostomum spp., they do not acquire the parasite by preying on other intermediate host fish, and thus can remove parasites from the pool of infective metacercariae in the system through their predatory actions.

The dynamics of Diplostomum spp. vary among hosts and habitats. Habitat differences between fluvial and wetland portions within the river affect food-web structure and piscivory, and subsequently alter the seasonal patterns of populations of eyeflukes in fish. Thus, population studies of parasites must take into account trophic relationships in a system, even if they are not directly involved in a parasite's life cycle.

\section{Ackowledgements}

We are grateful to Michel Arseneau, Germain Brault, and Karen $\mathrm{Ng}$ for their support in the field. We also thank Andrée Gendron for commenting on the manuscript. Andrée Gendron and François Boudreault are acknowledged for their graphics and logistic contributions. The constructive comments of two anonymous reviewers are greatly appreciated.

\section{References}

Bangham, R.V. 1955. Studies on fish parasites of Lake Huron and Manitoulin Island. Am. Midl. Nat. 53: 184-194.

Brassard, P., Rau, M.E., and Curtis, M.A. 1982a. Parasite-induced host susceptibility to predation in diplostomiasis. Parasitology, 85: 495-501.

Brassard, P., Rau, M.E., and Curtis, M.A. 1982b. Seasonality of Diplostomum spathaceum (Trematoda: Strigeidae) transmission to brook trout (Salvelinus fontinalis) in northern Quebec, Canada. Can. J. Zool. 60: 2258-2263.

Burrough, R.J. 1978. The population biology of two species of eyefluke, Diplostomum spathaceum and Tylodelphys clavata, in roach and rudd. J. Fish Biol. 13: 19-32.

Bush, A.O., Lafferty, K.D., Lotz, J.M., and Shostak, A.W. 1997. Parasitology meets ecology on its own terms: Margolis et al. revisited. J. Parasitol. 83: 575-583.

Chappell, L.H. 1995. The biology of diplostomatid eyeflukes of fishes. J. Helminthol. 69: 97-101.

Chappell, L.H., Hardie, L.J., and Secombes, C.J. 1994. Diplostomiasis: the disease and host-parasite interactions. In Parasitic diseases of fish. Edited by A.W. Pike and J.W. Lewis. Samara Publishing Ltd., Tresaith, Dyfed, Great Britain. pp. 59-86.

Crowden, A.E., and Broom, D.M. 1980. Effects of the eyefluke, Diplostomum spathaceum, on the behaviour of dace (Leuciscus leuciscus). Anim. Behav. 28: 287-294.
Dechtiar, A.O. 1972. Parasites of fish from Lake of the Woods, Ontario. J. Fish. Res. Board Can. 29: 275-283.

Dechtiar, A.O., and Christie, W.J. 1988. Survey of the parasite fauna of Lake Ontario fishes, 1961-1971. In Parasites of fishes in the Canadian waters of the Great Lakes. Edited by S.J. Nepszy. Gt. Lakes Fish. Comm. Tech. Rep. No. 51. pp. 66-95.

Dechtiar, A.O., and Lawrie, A.H. 1988. Survey of the parasite fauna of Lake Superior fishes, 1969-1975. In Parasites of fishes in the Canadian waters of the Great Lakes. Edited by S.J. Nepszy. Gt. Lakes Fish. Comm. Tech. Rep. No. 51. pp. 1-18.

Dechtiar, A.O., and Nepszy, S.J. 1988. Survey of the parasite fauna of selected fish species from Lake Erie. In Parasites of fishes in the Canadian waters of the Great Lakes. Edited by S.J. Nepszy. Gt. Lakes Fish. Comm. Tech. Rep. No. 51. pp. 49-65.

Dechtiar, A.O., Collins, J.J., and Reckahn, J.A. 1988. Survey of the parasite fauna of Lake Huron fishes, 1961-1971. In Parasites of fishes in the Canadian waters of the Great Lakes. Edited by S.J. Nepszy. Gt. Lakes Fish. Comm. Tech. Rep. No. 51. pp. 19-48.

Environment Canada. 2000. Ring-billed Gull. In The seabirds of the St. Lawrence, Quebec, Canada. Canadian Wildlife Service, Quebec. http://www.qc.ec.gc.ca/faune/oiseaux_de_mer/html/ringbill_gull.html (accessed on 16 February 2001).

Gagnon, M., Ménard, Y., and Lavergne, Y. 1991. Suivi environnemental de l'estuaire moyen du Saint-Laurent, 1989-1990 : variabilité spatio-temporelle de la structure des communautés et des populations ichtyennes. Rapp. Tech. Can. Sci. Halieut. Aquat. $1808 \mathrm{~F}$.

Gagnon, M., Ménard, Y., and Coutu, J.-M. 1992. Structure de la communauté ichtyenne intertidale de l'estuaire moyen du SaintLaurent : cadre de référence pour la suivi à long terme de l'état de l'écosystème de l'estuaire du Saint-Laurent. Tech. Can. Sci. Halieut. Aquat. $1870 \mathrm{~F}$.

Gibson, D.I. 1996. Guide to the parasites of fishes of Canada. Part IV. Trematoda. Can. Spec. Publ. Fish. Aquat. Sci. No. 124.

Hendrickson, G.L. 1978. Observations on strigeoid trematodes from the eyes of southeastern Wyoming fish. II. Diplostomum scheuringi Hughes, 1929; Neascus ptychocheilus (Faust, 1917); and other types. Proc. Helminthol. Soc. Wash. 45: 64-68.

Hoffman, G.L. 1999. Parasites of North American freshwater fishes. 2nd ed. Comstock Publishing Associates, Ithaca, N.Y.

Holmes, J.C. 1979. Parasite populations and host community structure. In Host-parasite interfaces. Edited by B.B. Nickol. Academic Press, New York. pp. 27-46.

Kennedy, C.R. 1981. Long term studies on the population biology of two species of eyefluke, Diplostomum gasterostei and Tylodelphys clavata (Digenea: Diplostomatidae), concurrently infecting the eyes of perch, Perca fluviatilis. J. Fish Biol. 19: 221-236.

Kennedy, C.R. 1987. Long-term stability in the population levels of the eyefluke Tylodelphys podicipina (Digenea: Diplostomatidae) in perch. J. Fish Biol. 31: 571-581.

Kennedy, C.R., and Burrough, R. 1977. The population biology of two species of eyefluke, Diplostomum gasterostei and Tylodelphys clavata, in perch. J. Fish Biol. 11: 619-633.

Levy, M. 1997. Helminth communities of ring-billed gulls (Larus delawarensis) collected along the St. Lawrence River and estuary. M.Sc. thesis, Concordia University, Montréal, Que.

Lyholt, H.C.K., and Buchmann, K. 1996. Diplostomum spathaceum: effects of temperature and light on cercarial shedding and infection of rainbow trout. Dis. Aquat. Org. 25: 169-173.

Marcogliese, D.J., and Compagna, S. 1999. Diplostomatid eyeflukes in young-of-the-year and forage fishes in the St. Lawrence River, Quebec. J. Aquat. Anim. Health, 11: 275-282. 
Marcogliese, D.J., Rodrigue, J., Ouelette, M., and Champoux, L. 2000. Natural occurrence of Diplostomum sp. (Digenea: Diplostomatidae) in adult mudpuppies and bullfrog tadpoles from the St. Lawrence River, Quebec. Comp. Parasitol. 67: 26-31.

Marcogliese, D.J., Dumont, P., Gendron, A.D., Mailhot, Y., Bergeron, E., and McLaughlin, J.D. 2001. Spatial and temporal variations in abundance of Diplostomum spp. in walleye (Stizostedion vitreum) and white sucker (Catostomus commersoni) from the St. Lawrence River: importance of gulls and fish stocks. Can. J. Zool. 79: $355-369$.

McKeown, C.A., and Irwin, S.W.B. 1997. Accumulation of Diplostomum spp. (Digenea: Diplostomatidae) metacercariae in the eyes of 0+ and 1+ roach (Rutilus rutilus). Int. J. Parasitol. 27: 377-380.

Owen, S.F., Barber, I., and Hart, P.J.B. 1993. Low level infection by eye fluke, Diplostomum spp., affects the vision of threespined sticklebacks, Gasterosteus aculeatus. J. Fish Biol. 42: 803-806.

Peer, D.L. 1966. Relationship between size and maturity in the spottail shiner, Notropis hudsonius. J. Fish. Res. Board Can. 23: 455-457.

Pennycuick, L. 1971. Seasonal variations in the parasite infections in a population of three-spined sticklebacks, Gasterosteus aculeatus L. Parasitology, 63: 373-388.

Shariff, M., Richards, R.R., and Sommerville, C. 1980. The histopathology of acute and chronic infections of rainbow trout
Salmo gairdneri Richardson with eye flukes, Diplostomum spp. J. Fish Dis. 3: 455-465.

Stables, J.N., and Chappell, L.H. 1986a. The epidemiology of diplostomiasis in farmed rainbow trout from north-east Scotland. Parasitology, 92: 699-710.

Stables, J.N., and Chappell, L.H. 1986b. Diplostomum spathaceum (Rud. 1819): effects of physical factors on the infection of rainbow trout (Salmo gairdneri) by cercariae. Parasitology, 93: 7179.

Stock, T.M., and Holmes, J.C. 1987. Host specificity and exchange of intestinal helminths among four species of grebes (Podicipedidae). Can. J. Zool. 65: 669-676.

Suns, K., and Rees, G.A. 1978. Organochlorine contaminant residues in young-of-the-year spottail shiners from lakes Ontario, Erie, and St. Clair. J. Gt. Lakes Res. 4: 230-233.

Tedla, S., and Fernando, C.H. 1969. Observations on the seasonal changes of the parasite fauna of yellow perch (Perca flavescens) from the Bay of Quinte, Lake Ontario. J. Fish. Res. Board Can. 26: $833-843$.

Tedla, S., and Fernando, C.H. 1970. On the characterization of the parasite fauna of yellow perch (Perca fluviatilis L.) in five lakes, in southern Ontario, Canada. Helminthologia, 11: 23-33.

Wootten, R. 1974. Observations on strigeid metacercariae in the eyes of fish from Hanningfield Reservoir, Essex, England. J. Helminthol. 48: 73-83. 